Article

\title{
Magnesium Pyrazolyl-Indolyl Complexes as Catalysts for Ring-Opening Polymerization of L-Lactide
}

\author{
Chi-Tien Chen *, Deng-Hao Lin and Kuo-Fu Peng \\ Received: 8 September 2015 ; Accepted: 23 September 2015 ; Published: 5 October 2015 \\ Academic Editor: Changle Chen \\ Department of Chemistry, National Chung Hsing University, Taichung 402, Taiwan; \\ chem13225@gmail.com (D.-H.L.); gPon@touchstone.tw (K.-F.P.) \\ * Correspondence: ctchen@dragon.nchu.edu.tw; Tel.: +886-4-2284-0412 (ext. 416); Fax: +886-4-2286-2547
}

\begin{abstract}
A series indole-based ligand precursors, $\mathrm{Pz}^{\mathrm{R}} \mathrm{IndH}\left(\mathrm{R}=\mathrm{H}, \mathrm{Pz}^{\mathrm{H}} \mathrm{IndH} ; \mathrm{R}=\mathrm{Me}, \mathrm{Pz}^{\mathrm{Me}} \mathrm{IndH}\right.$; $\mathrm{R}=\mathrm{t}-\mathrm{Bu}, \mathrm{Pz}{ }^{\mathrm{tBu}} \mathrm{IndH}$; and $\left.\mathrm{R}=\mathrm{Ph}, \mathrm{Pz}^{\mathrm{Ph}} \mathrm{IndH}\right)$, have been synthesized via copper-catalyzed $N$-arylation (for $\mathrm{Pz}^{\mathrm{H}} \mathrm{IndH}$ ) or the Bartoli indole synthesis (for $\mathrm{Pz}^{\mathrm{Me}} \mathrm{IndH}, \mathrm{Pz}^{\mathrm{tBu}} \mathrm{IndH}$ and $\mathrm{Pz}^{\mathrm{Ph}} \mathrm{IndH}$ ) reactions with moderate to high yield. Reactions of these ligand precursors with 0.7 equivalent of $\mathrm{Mg}^{\mathrm{n}} \mathrm{Bu}_{2}$ in THF (for $\mathbf{1}$ ) or hexane (for $\mathbf{2 - 4}$ ) afforded the bis-indolyl magnesium complexes $\mathbf{1}-\mathbf{4}$, respectively. All the ligand precursors and related magnesium complexes have been characterized by NMR spectroscopy and elemental analyses. The molecular structure is reported for compound $\mathbf{1}$. These novel magnesium complexes demonstrate efficient catalytic activities for the ring-opening polymerization of L-lactide in the presence of alcohol.
\end{abstract}

Keywords: magnesium; pyrazolyl; indolyl; ring-opening polymerization; biodegradable

\section{Introduction}

Polyesters, such as poly( $\varepsilon$-caprolactone) (PCL) or polylactide (PLA), are known as synthetic biodegradable polymers. These polymers have found applications in diverse fields, such as tissue engineering or bio-medical fields because of their biocompatible properties [1-5]. Due to the promising catalytic activities, metal-based initiators/catalysts have been attractive interest over the past decades [6-14]. Among these studies, some metal complexes bearing anionic $N$-heterocyclic ligands, such as pyrrole [15-26], indole [27,28] or carbazole [29], have displayed good catalytic activities towards ROP (ring-opening polymerization) of cyclic esters. The indole ring system, one of the most important heterocycles in nature, keeps continuous attraction due to the potential biological activities demonstrated by various indole derivatives. Therefore, development of novel routes for the preparation of indole derivatives has become an important theme in organic synthesis [30-34]. Recently, some magnesium complexes bearing pendant indolyl ligands have been reported by us [28]. They demonstrated efficient catalytic activities towards the ROP of cyclic esters. Considering the catalytic activities demonstrated by some pyrazolyl-containing magnesium complexes [35-38], we intended to introduce the pyrazolyl substituents as pendant functionalities into indole. We expected the combination of pyrazole and indole groups could be the candidates for ligand precursors. Therefore, we reported here the synthesis of magnesium complexes incorporating pyrazolyl-indolyl ligands. Their catalytic activities towards the ROP of L-lactide were also investigated. 


\section{Experimental Section}

\subsection{General Information}

All manipulations were carried out under an atmosphere of dinitrogen using standard Schlenk-line or drybox techniques. Solvents were refluxed over the appropriate drying agent and distilled prior to use. Deuterated solvents were dried over molecular sieves.

${ }^{1} \mathrm{H}$ and ${ }^{13} \mathrm{C}\left\{{ }^{1} \mathrm{H}\right\}$ NMR spectra were recorded either on Varian Mercury-400 (400 MHz) or Varian Inova-600 (600 MHz) spectrometers (Agilent Technologies, Santa Clara, CA, USA) in chloroform- $d$ or benzene- $d_{6}$ at room temperature unless stated otherwise and referenced internally to the residual solvent peak and reported as parts per million relative to tetramethylsilane. Elemental analyses were performed by an Elementar Vario ELIV instrument (Elementar, Hanau, Germany). The GPC measurements were performed in THF at $35{ }^{\circ} \mathrm{C}$ with a Waters 1515 isocratic HPLC pump, a Waters 2414 refractive index detector, and Waters styragel column (HR4E) (Waters, Milford, MA, USA). The number-average molecular weights $(M n)$ and molecular weight distributions (PDIs $=M w / M n$ ) were calculated using polystyrene as standard.

$\mathrm{N}, \mathrm{N}^{\prime}$-Dimethylethylenediamine (DMEDA, Acros, Geel, Belgium), pyrazole (Acros), $\mathrm{K}_{2} \mathrm{CO}_{3}$ (Union Chemical Works, Hsinchu, Taiwan), copper(I) iodide (Acros), 9-anthracenemethanol (9-AnOH, Acros), vinyl magnesium bromide (1.0 M in THF, Sigma-Aldrich, St. Louis, MO, USA) and di- $n$-butyl magnesium (1.0 $\mathrm{M}$ in heptane, Sigma-Aldrich) were used as supplied. Benzyl alcohol (TEDIA) was dried over $\mathrm{CaH}_{2}$ and distilled before use. L-Lactide (Bio Invigor, Taipei, Taiwan) was recrystallized from dry toluene prior to use. 7-Bromoindole [39], 3,5-dimethyl-1-(2-nitrophenyl)-1H-pyrazole [40], 3,5-di-tert-butyl-1-(2-nitrophenyl)-1H-pyrazole [40] and 3,5-diphenyl-1-(2-nitrophenyl)-1H-pyrazole [40] were prepared by the modified literature's methods.

\subsection{Preparations}

$\mathrm{Pz}^{\mathrm{H}}$ IndH: To a flask containing 7-bromoindole $(0.52 \mathrm{~g}, 2.70 \mathrm{mmol}), \mathrm{K}_{2} \mathrm{CO}_{3}(0.37 \mathrm{~g}, 2.70 \mathrm{mmol})$, $\mathrm{CuI}(0.05 \mathrm{~g}, 0.27 \mathrm{mmol})$ and $1 \mathrm{H}$-pyrazole $(0.20 \mathrm{~g}, 3 \mathrm{mmol}), 3 \mathrm{~mL}$ toluene and DMEDA $(0.07 \mathrm{~mL}$, $0.68 \mathrm{mmol}$ ) were added at room temperature under nitrogen. The reaction mixture was heated at $110{ }^{\circ} \mathrm{C}$ for 5 days. The reaction mixture was allowed to cool to room temperature. Then, the mixture was extracted with a mixed solution of $20 \mathrm{~mL}$ ethyl acetate and $50 \mathrm{~mL}$ de-ionized water. The organic layer was separated and dried over magnesium sulfate. The filtrate was pumped to dryness to afford yellow oil. Crude product was purified using column chromatography (ethyl acetate: $n$-hexane $=1: 10)$ to afford yellow oil. Yield, $0.35 \mathrm{~g}, 70 \% .{ }^{1} \mathrm{H} \mathrm{NMR}\left(\mathrm{CDCl}_{3}, 400 \mathrm{MHz}\right): \delta(\mathrm{ppm})$ $6.46(\mathrm{t}, J=2.0 \mathrm{~Hz}, 1 \mathrm{H}, \mathrm{Ar}-\mathrm{H}), 6.57(\mathrm{~m}, 1 \mathrm{H}, \mathrm{Ar}-\mathrm{H}), 7.09(\mathrm{~m}, 1 \mathrm{H}, \mathrm{Ar}-\mathrm{H}), 7.24(\mathrm{~d}, J=7.6 \mathrm{~Hz}, 1 \mathrm{H}, \mathrm{Ar}-\mathrm{H})$, $7.28(\mathrm{t}, J=3.2 \mathrm{~Hz}, 1 \mathrm{H}, \mathrm{Ar}-\mathrm{H}), 7.55(\mathrm{~d}, J=8.0 \mathrm{~Hz}, 1 \mathrm{H}, \mathrm{Ar}-\mathrm{H}), 7.76(\mathrm{~d}, J=1.2 \mathrm{~Hz}, 1 \mathrm{H}, \mathrm{Ar}-\mathrm{H}), 8.06$ (d, $J=2.4 \mathrm{~Hz}, 1 \mathrm{H}, \mathrm{Ar}-\mathrm{H}), 10.37$ (br, $1 \mathrm{H}, \mathrm{NH}) .{ }^{13} \mathrm{C}\left\{{ }^{1} \mathrm{H}\right\} \mathrm{NMR}\left(\mathrm{CDCl}_{3}, 100 \mathrm{MHz}\right): \delta(\mathrm{ppm}) 102.5,106.8$, 109.3, 118.9, 119.4, 125.3, 126.8, $140.4(\mathrm{Ar}-\mathrm{CH}), 125.1,127.4,130.7$ (tert-C). Anal. Calc. for $\mathrm{C}_{11} \mathrm{H}_{9} \mathrm{~N}_{3}$ (Mw. 183.21): C, 72.11\%; H, 4.95\%; N, 22.94\%. Found: C, 71.85\%; H, 4.95\%; N, 23.07\%.

$\mathrm{Pz} \mathrm{z}^{\mathrm{Me}} \mathrm{IndH}$ : To a flask containing 3,5-dimethyl-1-(2-nitrophenyl)-1H-pyrazole (0.65 g, $\left.3.0 \mathrm{mmol}\right)$ and $15 \mathrm{~mL}$ THF, $9 \mathrm{~mL}$ vinyl magnesium bromide $(1.0 \mathrm{M}$ in THF, $9 \mathrm{mmol})$ was added at $-45^{\circ} \mathrm{C}$. After $1 \mathrm{~h}$ of stirring, the reaction mixture was added $10 \mathrm{~mL}$ saturated $\mathrm{NH}_{4} \mathrm{Cl}$ (aq). The reaction mixture was allowed to warm to room temperature. Then, the mixture was extracted with a mixed solution of $20 \mathrm{~mL}$ ethyl alcohol and $50 \mathrm{~mL}$ de-ionized water. The organic layer was separated and dried over magnesium sulfate. The filtrate was pumped to dryness to afford brown oil. Crude product was purified using column chromatography (ethyl acetate: $n$-hexane $=1: 5$ ) to afford pale-yellow powder. Yield, $0.22 \mathrm{~g}, 35 \% .{ }^{1} \mathrm{H}$ NMR $\left(\mathrm{CDCl}_{3}, 400 \mathrm{MHz}\right): \delta(\mathrm{ppm}) 2.27\left(\mathrm{~s}, 3 \mathrm{H}, \mathrm{CH}_{3}\right), 2.34\left(\mathrm{~s}, 3 \mathrm{H}, \mathrm{CH}_{3}\right), 6.01$ (s, $1 \mathrm{H}, \mathrm{Pz}-\mathrm{H}), 6.50(\mathrm{t}, J=2.0 \mathrm{~Hz}, 1 \mathrm{H}, \mathrm{Ar}-\mathrm{H}), 7.04-7.12$ (overlap, 3H, Ar-H), $7.57(\mathrm{~d}, J=7.2 \mathrm{~Hz}, 1 \mathrm{H}, \mathrm{Ar}-\mathrm{H})$, 9.70 (br, $1 \mathrm{H}, \mathrm{NH}) .{ }^{13} \mathrm{C}\left\{{ }^{1} \mathrm{H}\right\} \mathrm{NMR}\left(\mathrm{CDCl}_{3}, 100 \mathrm{MHz}\right): \delta(\mathrm{ppm}) 12.6,13.5\left(\mathrm{CH}_{3}\right), 102.4,106.8,115.5,118.8$, 
119.6, 125.0 (Ar-CH), 124.3, 130.1, 130.3, 140.2, 149.1 (tert-C). Anal. Calc. for $\mathrm{C}_{13} \mathrm{H}_{13} \mathrm{~N}_{3}$ (Mw. 211.26): C, $73.91 \%$; H, $6.20 \%$; N, 19.89\%. Found: C, 73.54\%; H, 5.92\%; N, $19.88 \%$.

$P z^{t B u} I n d H$ : This was prepared in a similar method to that for $\mathrm{Pz}^{\mathrm{Me}}$ IndH by using 3,5-di-tert-butyl-1-(2-nitrophenyl)-1H-pyrazole $(0.90 \mathrm{~g}, 3.0 \mathrm{mmol})$. The brown oil was purified by column chromatography (ethyl acetate: $n$-hexane $=1: 5$ ) to afford pale-yellow solid. Yield, $0.33 \mathrm{~g}, 37 \%$. ${ }^{1} \mathrm{H}$ NMR $\left(\mathrm{CDCl}_{3}, 400 \mathrm{MHz}\right): \delta(\mathrm{ppm}) 1.10\left(\mathrm{~s}, 9 \mathrm{H}, \mathrm{C}\left(\mathrm{CH}_{3}\right)_{3}\right), 1.33\left(\mathrm{~s}, 9 \mathrm{H}, \mathrm{C}\left(\mathrm{CH}_{3}\right)_{3}\right), 6.08(\mathrm{~s}, 1 \mathrm{H}, \mathrm{Pz}-\mathrm{H})$, $6.41(\mathrm{t}, J=2.0 \mathrm{~Hz}, 1 \mathrm{H}, \mathrm{Ar}-\mathrm{H}), 6.94(\mathrm{t}, J=2.4 \mathrm{~Hz}, 1 \mathrm{H}, \mathrm{Ar}-\mathrm{H}), 7.07(\mathrm{t}, J=7.2 \mathrm{~Hz}, 1 \mathrm{H}, \mathrm{Ar}-\mathrm{H}), 7.19$ $(\mathrm{d}, J=7.2 \mathrm{~Hz}, 1 \mathrm{H}, \mathrm{Ar}-\mathrm{H}), 7.60(\mathrm{~d}, J=8.0 \mathrm{~Hz}, 1 \mathrm{H}, \mathrm{Ar}-\mathrm{H}), 8.45$ (br, $\left.1 \mathrm{H}, \mathrm{NH}) .{ }^{13} \mathrm{C}_{\{}{ }^{1} \mathrm{H}\right\} \mathrm{NMR}\left(\mathrm{CDCl}_{3}\right.$, $100 \mathrm{MHz}): \delta(\mathrm{ppm}) 30.3,30.6\left(\mathrm{C}_{\left.\left(\mathrm{CH}_{3}\right)_{3}\right)}\right), 31.9,32.0\left(\mathrm{C}_{\left.\left(\mathrm{CH}_{3}\right)_{3}\right), 100.5,102.6,118.8,121.3,121.7,124.9}\right.$ (Ar-CH), 126.4, 129.7, 133.5, 154.0, 161.3 (tert-C). Anal. Calc. for $\mathrm{C}_{19} \mathrm{H}_{25} \mathrm{~N}_{3}$ (Mw. 295.42): C, $77.25 \%$; $\mathrm{H}, 8.53 \% ; \mathrm{N}, 14.22 \%$. Found: C, $77.65 \% ; \mathrm{H}, 8.11 \% ; \mathrm{N}, 14.44 \%$.

$\mathrm{Pz}^{\mathrm{Ph}} \mathrm{IndH}$ : This was prepared in a similar method to that for $\mathrm{Pz}^{\mathrm{Me}} \mathrm{IndH}$ by using 3,5-diphenyl-1-(2-nitrophenyl)-1 $\mathrm{H}$-pyrazole $(1.02 \mathrm{~g}, 3.0 \mathrm{mmol})$. The pale-yellow powder was washed with $10 \mathrm{~mL}$ ethanol to afford white solid. Yield, $0.47 \mathrm{~g}, 47 \% .{ }^{1} \mathrm{H} \mathrm{NMR}\left(\mathrm{CDCl}_{3}, 400 \mathrm{MHz}\right): \delta(\mathrm{ppm})$ $6.59(\mathrm{t}, J=2.4 \mathrm{~Hz}, 1 \mathrm{H}, \mathrm{Ar}-\mathrm{H}), 6.69(\mathrm{~d}, J=7.2 \mathrm{~Hz}, 1 \mathrm{H}, \mathrm{Ar}-\mathrm{H}), 6.83(\mathrm{~s}, 1 \mathrm{H}, \mathrm{Ar}-\mathrm{H}), 6.86(\mathrm{t}, J=8.0 \mathrm{~Hz}$, $1 \mathrm{H}, \mathrm{Ar}-\mathrm{H}$ ), $7.23(\mathrm{t}, J=2.8 \mathrm{~Hz}, 1 \mathrm{H}, \mathrm{Ar}-\mathrm{H}$ ), 7.25-7.35 (overlap, 5H, Ar-H), 7.41-7.44 (overlap, 2H, Ar-H), $7.54(\mathrm{~d}, J=8.0 \mathrm{~Hz}, 1 \mathrm{H}, \mathrm{Ar}-\mathrm{H}), 7.91-7.93$ (overlap, $2 \mathrm{H}, \mathrm{Ar}-\mathrm{H}), 9.44(\mathrm{br}, 1 \mathrm{H}, \mathrm{NH}) .{ }^{13} \mathrm{C}\left\{{ }^{1} \mathrm{H}\right\} \mathrm{NMR}$ $\left(\mathrm{CDCl}_{3}, 100 \mathrm{MHz}\right): \delta(\mathrm{ppm}) 102.9,105.2,117.3,119.0,119.8,125.2,125.7,128.2,128.4,128.6,128.7,130.5$ (Ar-CH), 124.3, 130.1, 130.3, 132.8, 145.0, 152.0 (tert-C). Anal. Calc. for $\mathrm{C}_{23} \mathrm{H}_{17} \mathrm{~N}_{3}$ (Mw. 335.40): $\mathrm{C}$, $82.36 \% ; \mathrm{H}, 5.11 \%$; N $12.13 \%$. Found: C, $82.65 \%$; H, 5.19\%; N, $12.13 \%$.

$\left[\mathrm{Pz}^{\mathrm{H}} \text { Ind }\right]_{2} \mathrm{Mg}$. 2THF (1): To a flask containing Pz ${ }^{\mathrm{H}} \mathrm{IndH}(0.183 \mathrm{~g}, 1.0 \mathrm{mmol})$ in $15 \mathrm{~mL}$ THF, $0.7 \mathrm{~mL}$ di- $n$-butyl magnesium $(1.0 \mathrm{M}, 0.7 \mathrm{mmol})$ was added at $0{ }^{\circ} \mathrm{C}$. The reaction mixture was allowed to warm up to room temperature. After $16 \mathrm{~h}$ of stirring, the reaction mixture was filtered and off-white solid was washed with $5 \mathrm{~mL}$ hexane. The residue was pumped to dryness to afford white solid. Yield, $0.27 \mathrm{~g}, 54 \% .{ }^{1} \mathrm{H}$ NMR $\left(\mathrm{CDCl}_{3}, 600 \mathrm{MHz}\right): \delta(\mathrm{ppm}) 1.67\left(\mathrm{br}, 8 \mathrm{H}, \mathrm{CH}_{2}\right), 3.48\left(\mathrm{br}, 8 \mathrm{H}, \mathrm{OCH}_{2}\right), 6.41(\mathrm{~s}, 2 \mathrm{H}$, $\mathrm{Ar}-\mathrm{H}), 6.67(\mathrm{~d}, J=2.4 \mathrm{~Hz}, 2 \mathrm{H}, \mathrm{Ar}-\mathrm{H}), 7.01(\mathrm{t}, J=7.8 \mathrm{~Hz}, 2 \mathrm{H}, \mathrm{Ar}-\mathrm{H}), 7.19(\mathrm{~d}, J=7.2 \mathrm{~Hz}, 2 \mathrm{H}, \mathrm{Ar}-\mathrm{H})$, $7.53(\mathrm{~s}, 2 \mathrm{H}, \mathrm{Ar}-\mathrm{H}), 7.60(\mathrm{~s}, 2 \mathrm{H}, \mathrm{Ar}-\mathrm{H}), 7.68(\mathrm{~d}, J=7.8 \mathrm{~Hz}, 2 \mathrm{H}, \mathrm{Ar}-\mathrm{H}), 8.27(\mathrm{~d}, J=1.8 \mathrm{~Hz}, 2 \mathrm{H}, \mathrm{Ar}-\mathrm{H})$. $\left.{ }^{13} \mathrm{C}_{\{}{ }^{1} \mathrm{H}\right\}$ NMR $\left(\mathrm{CDCl}_{3}, 150 \mathrm{MHz}\right): \delta(\mathrm{ppm}) 25.2\left(\mathrm{CH}_{2}\right), 68.4\left(\mathrm{OCH}_{2}\right), 101.4,106.8,107.3,116.2,119.0$, 125.3, 128.8, 141.8 (Ar-CH), 134.1, 134.6, 136.7 (tert-C). Anal. Calc. for $\mathrm{C}_{30} \mathrm{H}_{32} \mathrm{MgN}_{6} \mathrm{O}_{2}$ (Mw. 532.92): C, $67.61 \% ; \mathrm{H}, 6.05 \%$; N, $15.77 \%$. Found: C, $66.70 \% ; \mathrm{H}, 5.49 \%$; N, $15.60 \%$.

$\left[\mathrm{Pz}^{\mathrm{Me}} \mathrm{Ind}\right]_{2} \mathrm{Mg}$ (2): To a flask containing $\mathrm{Pz}^{\mathrm{Me}} \mathrm{IndH}(0.21 \mathrm{~g}, 1.0 \mathrm{mmol})$ in $15 \mathrm{~mL}$ hexane, $0.7 \mathrm{~mL}$ di-n-butyl magnesium $(1.0 \mathrm{M}, 0.7 \mathrm{mmol})$ was added at $0{ }^{\circ} \mathrm{C}$. The reaction mixture was allowed to warm up to room temperature. After $16 \mathrm{~h}$ of stirring, the reaction mixture was filtered to afford white solid. Yield, $0.27 \mathrm{~g}, 61 \% .{ }^{1} \mathrm{H}$ NMR $\left(\mathrm{C}_{6} \mathrm{D}_{6}, 600 \mathrm{MHz}\right): \delta(\mathrm{ppm}) 1.26\left(\mathrm{~s}, 6 \mathrm{H}, \mathrm{CH}_{3}\right), 1.88\left(\mathrm{~s}, 6 \mathrm{H}, \mathrm{CH}_{3}\right), 5.33$ $(\mathrm{s}, 2 \mathrm{H}, \mathrm{Ar}-\mathrm{H}), 6.79(\mathrm{~d}, J=7.2 \mathrm{~Hz}, 2 \mathrm{H}, \mathrm{Ar}-\mathrm{H}), 7.03(\mathrm{~d}, J=2.4 \mathrm{~Hz}, 2 \mathrm{H}, \mathrm{Ar}-\mathrm{H}), 7.10(\mathrm{t}, J=7.8 \mathrm{~Hz}, 2 \mathrm{H}$, $\mathrm{Ar}-\mathrm{H}), 7.58(\mathrm{~d}, J=2.4 \mathrm{~Hz}, 2 \mathrm{H}, \mathrm{Ar}-\mathrm{H}), 7.96(\mathrm{~d}, J=7.8 \mathrm{~Hz}, 2 \mathrm{H}, \mathrm{Ar}-\mathrm{H}) .{ }^{13} \mathrm{C}\left\{{ }^{1} \mathrm{H}\right\} \mathrm{NMR}\left(\mathrm{C}_{6} \mathrm{D}_{6}, 150 \mathrm{MHz}\right)$ : $\delta(\mathrm{ppm})$ 11.2, $13.8\left(\mathrm{CH}_{3}\right), 103.9,108.8,112.9,116.2,120.6,137.0(\mathrm{Ar}-\mathrm{CH}), 124.4,135.3,138.4,144.2,151.7$ (tert-C). Anal. Calc. for $\mathrm{C}_{26} \mathrm{H}_{24} \mathrm{~N}_{6} \mathrm{Mg}$ (Mw. 444.81): C, 70.20\%; H, 5.44\%; N, $18.89 \%$. Found: C, $70.94 \% ; \mathrm{H}, 6.01 \%$; N $18.65 \%$.

$\left[\mathrm{Pz}^{t B u} \operatorname{Ind}\right]_{2} \mathrm{Mg}$ (3): This was prepared in a similar method to that for 2 by using $\mathrm{Pz}^{\mathrm{tBu}} \operatorname{IndH}(0.29 \mathrm{~g}$, $1.0 \mathrm{mmol})$ to afford white solid. Yield, $0.45 \mathrm{~g}, 73 \% .{ }^{1} \mathrm{H}$ NMR $\left(\mathrm{C}_{6} \mathrm{D}_{6}, 600 \mathrm{MHz}\right): \delta(\mathrm{ppm}) 0.92(\mathrm{br}, 18 \mathrm{H}$, $\left.\mathrm{C}\left(\mathrm{CH}_{3}\right)_{3}\right), 1.10\left(\mathrm{~s}, 18 \mathrm{H}, \mathrm{C}\left(\mathrm{CH}_{3}\right)_{3}\right), 6.23$ (br, 2H, Ar-H), 6.91 (br, $\left.2 \mathrm{H}, \mathrm{Ar}-\mathrm{H}\right), 6.96-7.02$ (overlap, $4 \mathrm{H}$, Ar-H), 7.18 (br, 2H, Ar-H), $7.93(\mathrm{~d}, J=7.2 \mathrm{~Hz}, 2 \mathrm{H}, \mathrm{Ar}-\mathrm{H}) .{ }^{13} \mathrm{C}\left\{{ }^{1} \mathrm{H}\right\} \mathrm{NMR}\left(\mathrm{C}_{6} \mathrm{D}_{6}, 150 \mathrm{MHz}\right): \delta$ (ppm)

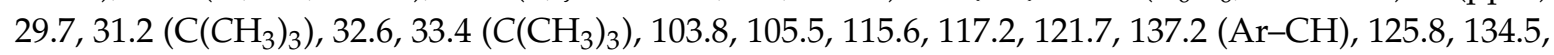
140.2, 160.7, 167.9 (tert-C). Anal. Calc. for $\mathrm{C}_{38} \mathrm{H}_{48} \mathrm{~N}_{6} \mathrm{Mg}$ (Mw. 613.13): C, 74.44\%; $\mathrm{H}, 7.89 \%$;, $13.71 \%$. Found: C, $74.51 \% ; \mathrm{H}, 8.14 \%$; N, $13.72 \%$.

$\left[\mathrm{Pz}^{\mathrm{Ph}} I n d\right]_{2} \mathrm{Mg}(4)$ : This was prepared in a similar method to that for 2 by using $\mathrm{Pz}^{\mathrm{Ph}} \operatorname{IndH}(0.33 \mathrm{~g}$, $1.0 \mathrm{mmol})$ to afford white solid. Yield, $0.45 \mathrm{~g}, 65 \% .{ }^{1} \mathrm{H} \mathrm{NMR}\left(\mathrm{CDCl}_{3}, 400 \mathrm{MHz}\right): \delta(\mathrm{ppm}) 6.34(\mathrm{~d}$, $J=7.6 \mathrm{~Hz}, 2 \mathrm{H}, \mathrm{Ar}-\mathrm{H}), 6.55(\mathrm{~d}, J=2.4 \mathrm{~Hz}, 2 \mathrm{H}, \mathrm{Ar}-\mathrm{H}), 6.60-6.64(\mathrm{~m}, 4 \mathrm{H}, \mathrm{Ar}-\mathrm{H}), 6.85-6.92$ (overlap, $6 \mathrm{H}, \mathrm{Ar}-\mathrm{H}), 7.16(\mathrm{~d}, J=2.4 \mathrm{~Hz}, 2 \mathrm{H}, \mathrm{Ar}-\mathrm{H}), 7.28(\mathrm{~d}, J=8.0 \mathrm{~Hz}, 4 \mathrm{H}, \mathrm{Ar}-\mathrm{H}), 7.34-7.43$ (overlap, 10H, 
$\mathrm{Ar}-\mathrm{H}), 7.57(\mathrm{~d}, J=8.0 \mathrm{~Hz}, 2 \mathrm{H}, \mathrm{Ar}-\mathrm{H}) .{ }^{13} \mathrm{C}\left\{{ }^{1} \mathrm{H}\right\} \mathrm{NMR}\left(\mathrm{CDCl}_{3}, 150 \mathrm{MHz}\right): \delta(\mathrm{ppm}) 102.4,106.8,115.28$, 115.35, 119.8, 128.5, 128.7, 129.1, 129.2, 129.3, 137.0 (Ar-CH), 123.4, 129.4, 130.0, 134.1, 137.3, 148.2, 155.0 (tert-C). Anal. Calc. for $\mathrm{C}_{46} \mathrm{H}_{32} \mathrm{~N}_{6} \mathrm{Mg}$ (Mw. 693.09): C, 79.71\%; H, 4.65\%; N, $12.13 \%$. Found: $\mathrm{C}$, $79.05 \% ; \mathrm{H}, 5.01 \%$; N, $11.82 \%$.

Procedure for Polymerization of L-Lactide: Typically, to a flask containing prescribed amount of L-lactide, $0.025 \mathrm{mmol}$ alcohol and $0.025 \mathrm{mmol}$ catalyst precursor was added $5.0 \mathrm{~mL}$ solvent. The reaction mixture was stirred at prescribed temperature for the prescribed time. After the reaction was quenched by the addition of $2.5 \mathrm{~mL}$ acetic acid solution $(0.35 \mathrm{~N})$, the resulting mixture was poured into $20 \mathrm{~mL} n$-hexane to precipitate polymers. Crude products were recrystallized from THF/hexane and dried in vacuo up to a constant weight.

\subsection{Crystal Structure Data}

Crystals were grown from concentrated THF solution for 1, and isolated by filtration. Suitable crystals were mounted onto Mounted CryoLoop (HAMPTON RESEARCH, Aliso Viejo, CA, USA; size: $0.5-0.7 \mathrm{~mm}$ ) using perfluoropolyether oil (Sigma-Aldrich, FOMBLIN ${ }^{\circledR} \mathrm{Y}$ ) and cooled rapidly in a stream of cold nitrogen gas using an Oxford Cryosystems Cryostream unit. Diffraction data were collected at $100 \mathrm{~K}$ using an OxfordGemini S diffractometer (Oxford Diffraction Ltd., Abingdon, UK). Empirical absorption correction was based on spherical harmonics, implemented in the SCALE3 ABSPACK scaling algorithm from CrysAlis RED (Oxford Diffraction Ltd.). The space group determination was based on a check of the Laue symmetry and systematic absences and was confirmed using the structure solution. The structure was solved by direct methods using a SHELXTL package [41]. All non-H atoms were located from successive Fourier maps, and hydrogen atoms were refined using a riding model. Anisotropic thermal parameters were used for all non-H atoms, and fixed isotropic parameters were used for $\mathrm{H}$ atoms. Some details of the data collection and refinement are given in Table 1.

CCDC reference number 1410371 for 1 contains the supplementary crystallographic data for this paper. These data can be obtained free of charge from The Cambridge Crystallographic Data Centre via www.ccdc.cam.ac.uk/data_request/cif.

Table 1. Summary of crystal data for compound $\mathbf{1 .}$

\begin{tabular}{|c|c|}
\hline Parameters & 1 \\
\hline Formula & $\mathrm{C}_{30} \mathrm{H}_{32} \mathrm{MgN}_{6} \mathrm{O}_{2}$ \\
\hline$F_{\mathrm{w}}$ & 532.93 \\
\hline$T, \mathrm{~K}$ & $100(2)$ \\
\hline Crystal system & Trigonal \\
\hline Space group & $R-3 c$ \\
\hline$a, \AA$ & $23.6115(3)$ \\
\hline$b, \AA$ & $23.6115(3)$ \\
\hline$c, \AA$ & $26.0131(5)$ \\
\hline$\gamma,{ }^{\circ}$ & 120 \\
\hline$V, \AA^{3}$ & $12,559.4(3)$ \\
\hline $\mathrm{Z}$ & 18 \\
\hline$\rho_{\text {calc }}, \mathrm{Mg} / \mathrm{m}^{3}$ & 1.268 \\
\hline$\mu\left(\mathrm{Mo} \mathrm{K}_{\alpha}\right), \mathrm{mm}^{-1}$ & 0.102 \\
\hline$F(000)$ & 5076 \\
\hline Crystal size & $0.60 \times 0.45 \times 0.30 \mathrm{~mm}^{3}$ \\
\hline Theta range for data collection & $2.91^{\circ}$ to $29.24^{\circ}$ \\
\hline Reflections collected & 25,170 \\
\hline Independent reflections & $3490[\mathrm{R}(\mathrm{int})=0.0269]$ \\
\hline No. of parameters & 177 \\
\hline$R 1^{\mathrm{a}}$ & 0.0337 \\
\hline$w R 2^{\mathrm{a}}$ & 0.0893 \\
\hline $\mathrm{GoF}^{\mathrm{b}}$ & 1.002 \\
\hline
\end{tabular}




\section{Results and Discussion}

\subsection{Preparations of Ligand Precursors and Magnesium Complexes}

There are various synthetic routes for the preparation of indole derivatives, such as Fischer indole synthesis [32], Bartoli indole synthesis [31] or Pd/Cu-catalyzed cyclization [42,43]. Previously, we reported the preparation of indole bearing pendant functionalities using the Sonogashira reaction followed by Zn-mediated cyclization [28]. In order to introduce pyrazolyl functionalities into indole molecules, copper-catalyzed $\mathrm{N}$-arylation or the Bartoli indole synthesis are used to achieve this issue. The synthetic routes were shown in Scheme 1.

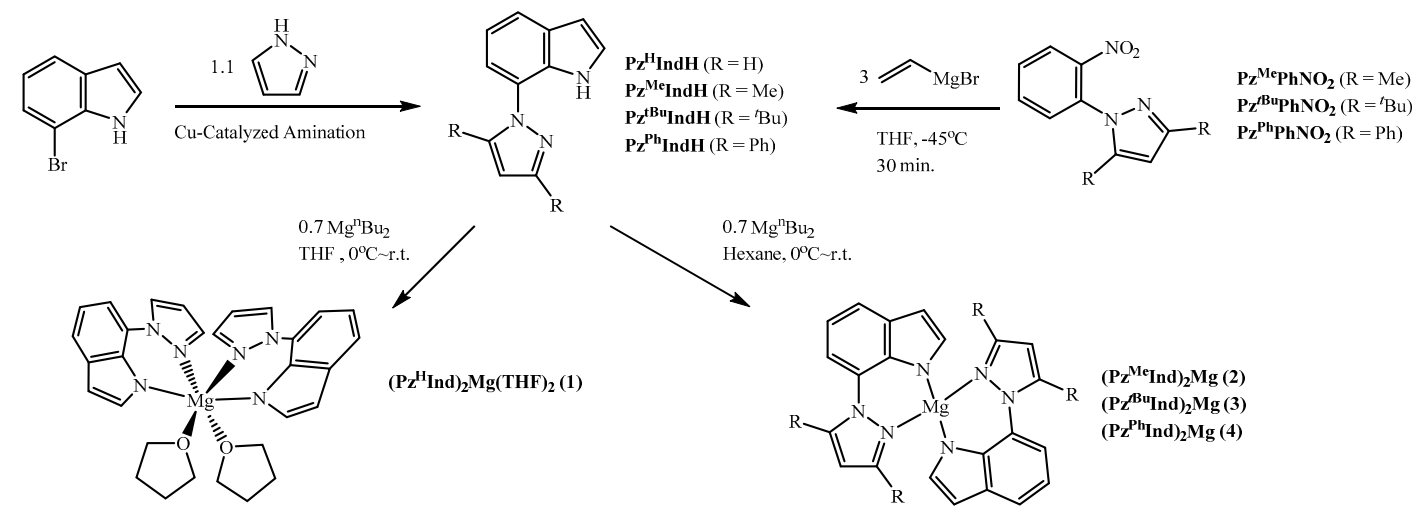

Scheme 1. Synthetic routes for ligand precursors and magnesium complexes.

The ligand precursor $\mathrm{Pz}^{\mathrm{H}} \mathrm{IndH}$ was prepared via copper-catalyzed $\mathrm{N}$-arylation reaction from 7-bromoindole with pyrazole [44]. Related ligand precursors composed of pyrazolyl rings bound to carbazole at the 1- and 8-positions have recently been reported [45]. The signal of - NH on ${ }^{1} \mathrm{H} N M R$ spectrum for indole $\mathrm{Pz}^{\mathrm{H}}$ IndH was observed at $\delta 10.37 \mathrm{ppm}$. The ligand precursors $\mathrm{Pz}^{\mathrm{Me}} \mathrm{IndH}$, $\mathrm{Pz}^{\mathrm{tBu}} \mathrm{IndH}$ and $\mathrm{Pz}^{\mathrm{Ph}}$ IndH were prepared via the Bartoli indole synthesis from $o$-substituted nitrobenzenes with vinylmagnesium bromide [31]. The signals of $-\mathrm{NH}$ on ${ }^{1} \mathrm{H}$ NMR spectra for indoles $\mathrm{Pz}^{\mathrm{Me}} \mathrm{IndH}, \mathrm{Pz}^{\mathrm{tBu}}$ IndH and $\mathrm{Pz}^{\mathrm{Ph}} \mathrm{IndH}$ were observed at $\delta 9.70,8.45$, and 9.44 ppm, respectively. All the ligand precursors were characterized by elemental analyses as well.

Treatment of ligand precursors $\mathrm{Pz}^{\mathrm{R}} \mathrm{IndH}$ with ${ }^{\mathrm{n}} \mathrm{Bu}_{2} \mathrm{Mg}$ on the ratio of 1:0.7 by alkane elimination reaction in THF or hexane at room temperature affords the desired bis-indolyl magnesium complexes 1-4 in moderate yields, as shown in Scheme 1. For compound 1, the disappearance of the $\mathrm{N}-\mathrm{H}$ signal of indole and the appearance of the coordinated THF are consistent with the proposed structure. Preparations of compounds 2-4 bearing the coordinated THF have been done in THF. However, the signals corresponding to coordinated THF disappeared after rinsing the crude products with hexane. For the convenience of separation, THF was used to prepare compound 1, whereas hexane was used to prepare compounds $2-4$. The compounds 1-4 were all characterized by NMR spectroscopy as well as elemental analyses.

Suitable crystals for structure determination of 1 were obtained from concentrated THF solution. The molecular structure is depicted in Figure 1. Selected bond lengths and bond angles are summarized in Table 2.

The solid state structure of $\mathbf{1}$ reveals that the $\mathrm{Mg}$ center adopts a distorted octahedral geometry $\left(\mathrm{N}_{\text {pyrazole }}-\mathrm{Mg}-\mathrm{O}_{\mathrm{THF}} 175.46(3)^{\circ} ; \mathrm{N}_{\text {indolyl }}-\mathrm{Mg}-\mathrm{N}_{\text {indolyl }} 169.40(5)^{\circ}\right)$ with the metal center chelated by two nitrogen atoms of indole rings, two nitrogen atoms of pyrazole rings and two oxygen atoms of coordinated THF. According to the coordinated THF positions of related magnesium complexes in the literature [46-48], the cis-configuration for 1 is observed $\left(\mathrm{O}_{\mathrm{THF}}-\mathrm{Mg}-\mathrm{O}_{\mathrm{THF}}, 87.62(4)^{\circ}\right)$. The $\mathrm{Mg}-\mathrm{O}_{\mathrm{THF}}$ bond length of $\mathbf{1}(2.1516(8) \AA)$ is longer than those found in cis-form (2.0661(10)-2.136(5) $⿱$ ) [46-48]. 
The $\mathrm{Mg}-\mathrm{N}_{\text {indolyl }}$ bond lengths (2.1067(9) $\AA$ ) are close to those found in magnesium bis-indolyl complexes (2.0907(16) $\AA$ for trans-form; 2.126(2) and 2.138(2) $\AA$ for cis-form) [28]. The Mg- $\mathrm{N}_{\text {pyrazole }}$ bond lengths $(2.2156(9) \AA)$ are within those found in magnesium complexes bearing pyrazole functionality (2.100(3)-2.21(1) ̊) [35-38].

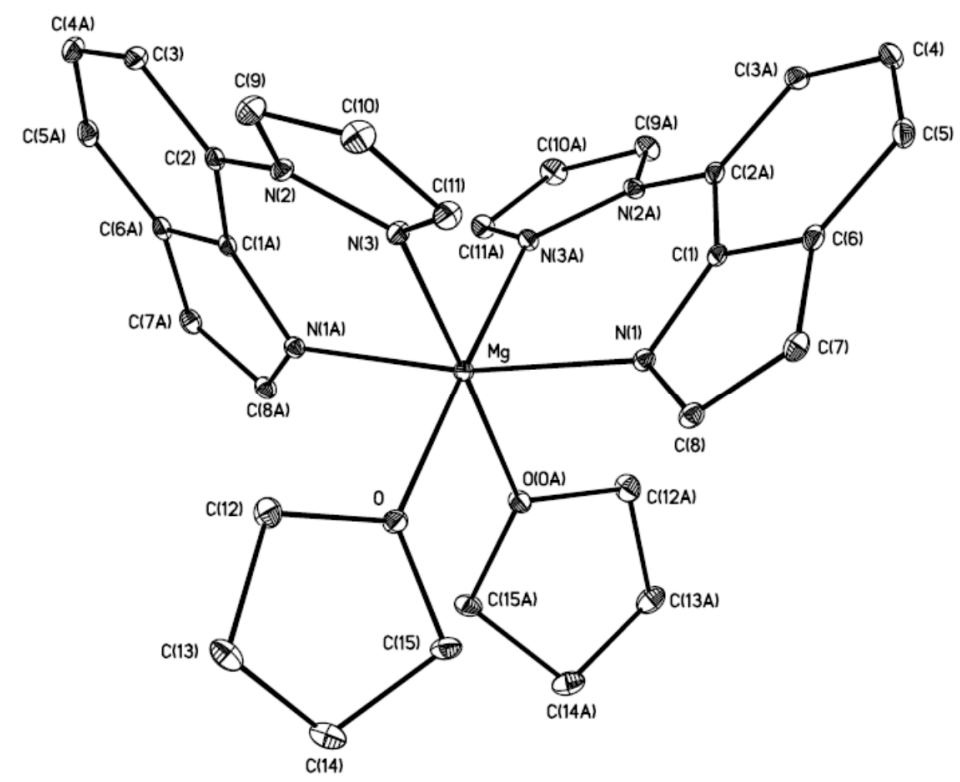

Figure 1. Molecular structure of $\mathbf{1}$. Hydrogen atoms are omitted for clarity.

Table 2. Selected bond lengths $(\AA)$ and bond angles $\left(^{\circ}\right)$ for $\mathbf{1}$.

\begin{tabular}{cccc}
\hline Selected Bonds & $(\AA)$ & Selected Bond Angles & $\left({ }^{\circ}\right)$ \\
\hline $\mathrm{Mg}-\mathrm{N}(1)$ & $2.1067(9)$ & $\mathrm{N}(1)-\mathrm{Mg}-\mathrm{N}(1 \mathrm{~A})$ & $169.40(5)$ \\
$\mathrm{Mg}-\mathrm{N}(3)$ & $2.2156(9)$ & $\mathrm{N}(1)-\mathrm{Mg}-\mathrm{N}(3 \mathrm{~A})$ & $85.05(3)$ \\
$\mathrm{Mg}-\mathrm{O}$ & $2.1516(8)$ & $\mathrm{O}-\mathrm{Mg}-\mathrm{O}(0 \mathrm{~A})$ & $87.62(4)$ \\
& & $\mathrm{N}(3)-\mathrm{Mg}-\mathrm{O}(0 \mathrm{~A})$ & $175.46(3)$ \\
& & $\mathrm{N}(1)-\mathrm{Mg}-\mathrm{O}(0 \mathrm{~A})$ & $91.36(3)$ \\
& & $\mathrm{N}(3)-\mathrm{Mg}-\mathrm{N}(3 \mathrm{~A})$ & $96.38(5)$ \\
\hline
\end{tabular}

\subsection{Polymerization Studies}

Since several magnesium complexes containing bis-indolyl ligands have demonstrated their catalytic activities towards the ROP of cyclic esters in the presence of alcohols [28], the homoleptic indolyl magnesium complexes reported here are expected to work as the catalysts for the ring opening polymerization. Representative results are collected in Table 3 for ROP of L-LA, respectively.

The polymerization of L-lactide using complexes 1-4 as catalyst precursors in the presence of alcohols is tested under a dry nitrogen atmosphere. Prescribed equivalent ratios on the catalyst precursor $(0.025 \mathrm{mmol})$, L-LA and alcohol were introduced in $5.0 \mathrm{~mL}$ solvent at $0{ }^{\circ} \mathrm{C}$ for $1 \mathrm{~min}$. After several trials on running polymerization with various solvents (dichloromethane, tetrahydrofuran or toluene) and alcohols (benzyl alcohol $(\mathrm{BnOH}), 2$-propanol $\left({ }^{\mathrm{i}} \mathrm{PrOH}\right)$ and 9-anthracenemethanol $(9-\mathrm{AnOH})$ ), the conditions were optimized to be toluene at $0{ }^{\circ} \mathrm{C}$ in the presence of $9-\mathrm{AnOH}$ for the polymerization of L-LA (Table 1, Entries 1-5). However, only trace polymers were obtained from the blank tests in the absence of benzyl alcohol or 4 under the optimized conditions (Table 1, Entries 6-7). The same optimized conditions were applied to examine the catalytic activities of these catalysts with the reaction time extended to $5 \mathrm{~min}$ (Table 1, Entries 8-11). Only trace polymers obtained by using 1 as catalyst, this is consistent with the result demonstrated by magnesium bis-indolyl 
complex with pendant amine functionality and coordinated THF molecules [28]. The bulkiness around the metal center caused by ligands and coordinated THF molecules might prevent the metal center from the coordination of monomers and alcohol. The catalytic activities exhibited by the other complexes without coordinated THF molecule seem to depend on the steric hindrance resulting from the substituents on the pyrazolyl groups. The decreasing tendency of catalytic activity was found in the order $3>4>2$. The catalytic activities were re-examined on the ratio of $[\mathrm{L}-\mathrm{LA}]_{0} /[\mathrm{Mg}]_{0} /[9-\mathrm{AnOH}]_{0}=200 / 1 / 1$ within $15 \mathrm{~min}$. (Table 1, Entries 12-13). Complex 4 showed better activities than 3 with better controlled character. Therefore, complex 4 was subjected to exhibit the living character at $30^{\circ} \mathrm{C}$. The linear relationship between the number-average molecular weight $(\mathrm{Mn})$ and the monomer-to-initiator ratio (range from 150 to 400) was demonstrated in Figure 2 (Table 1, Entries 14-19, PDIs = 1.22-1.39) with poor controlled character.

Table 3. Polymerization of L-LA using compounds $1-4$ as catalysts in toluene if not otherwise stated. ${ }^{a}$

\begin{tabular}{|c|c|c|c|c|c|c|c|c|}
\hline Entry & Catalyst & {$[\mathrm{LA}]_{0}:[\mathrm{Mg}]_{0}:[\mathrm{ROH}]$} & $\begin{array}{c}T \\
\left({ }^{\circ} \mathrm{C}\right)\end{array}$ & $\begin{array}{c}t \\
(\min )\end{array}$ & $\begin{array}{c}M \mathrm{n} \\
\text { (obsd) }^{b}\end{array}$ & $\begin{array}{c}M \mathbf{n} \\
\text { (calcd) }^{c}\end{array}$ & $\begin{array}{c}\text { Conversion } \\
(\%)^{d}\end{array}$ & $M w / M n^{b}$ \\
\hline 1 & 4 & 100:1:1 & 0 & 1 & 14,000 & 10,300 & 70 & 1.20 \\
\hline $2^{\mathrm{e}}$ & 4 & $100: 1: 1$ & 0 & 1 & - & - & 61 & - \\
\hline $3^{f}$ & 4 & 100:1:1 & 0 & 1 & - & - & 6 & - \\
\hline $4^{g}$ & 4 & $100: 1: 1$ & 0 & 1 & - & - & 20 & - \\
\hline $5^{\mathrm{h}}$ & 4 & 100:1:1 & 0 & 1 & - & - & 15 & - \\
\hline 6 & 4 & $100: 1: 0$ & 0 & 1 & - & - & trace & - \\
\hline 7 & 4 & 100:0:1 & 0 & 1 & - & - & trace & - \\
\hline 8 & 1 & $100: 1: 1$ & 0 & 5 & - & - & trace & - \\
\hline 9 & 2 & $100: 1: 1$ & 0 & 5 & 18,800 & 11,700 & 80 & 1.05 \\
\hline 10 & 3 & $100: 1: 1$ & 0 & 5 & 24,200 & 14,300 & 98 & 1.38 \\
\hline 11 & 4 & $100: 1: 1$ & 0 & 5 & 17,400 & 13,600 & 93 & 1.25 \\
\hline 12 & 3 & $200: 1: 1$ & 0 & 15 & 33,400 & 25,800 & 89 & 1.42 \\
\hline 13 & 4 & 200:1:1 & 0 & 15 & 27,800 & 27,600 & 95 & 1.24 \\
\hline 14 & 4 & $150: 1: 1$ & 30 & 3 & 27,000 & 21,000 & 96 & 1.29 \\
\hline 15 & 4 & $200: 1: 1$ & 30 & 5 & 33,000 & 28,700 & 99 & 1.39 \\
\hline 16 & 4 & $250: 1: 1$ & 30 & 7 & 41,900 & 35,500 & 98 & 1.38 \\
\hline 17 & 4 & $300: 1: 1$ & 30 & 10 & 46,200 & 42,600 & 98 & 1.36 \\
\hline 18 & 4 & $350: 1: 1$ & 30 & 15 & 48,500 & 50,100 & 99 & 1.22 \\
\hline 19 & 4 & $400: 1: 1$ & 30 & 20 & 55,800 & 57,200 & 99 & 1.32 \\
\hline 20 & 4 & $600: 1: 2$ & 30 & 12 & 43,600 & 42,800 & 99 & 1.20 \\
\hline 21 & 4 & $600: 1: 3$ & 30 & 7 & 31,100 & 28,200 & 98 & 1.20 \\
\hline 22 & 4 & $600: 1: 4$ & 30 & 5 & 23,200 & 21,200 & 98 & 1.19 \\
\hline
\end{tabular}

${ }^{\mathrm{a}},[\mathrm{Mg}]_{0}=[9-\mathrm{AnOH}]=0.025 \mathrm{mmol}$ in $5.0 \mathrm{~mL}$ toluene; ${ }^{\mathrm{b}}$, Obtained from GPC analysis times $0.58 ;{ }^{\mathrm{c}}$, Calculated from the molecular weight of lactide times $[\mathrm{LA}]_{0} /[\mathrm{RO} H]_{0}$ times conversion yield plus the molecular weight of $\mathrm{ROH}$; ${ }^{\mathrm{d}}$, Obtained from ${ }^{1} \mathrm{H}$ NMR analysis; ${ }^{\mathrm{e}}$, In $5.0 \mathrm{~mL} \mathrm{CH}_{2} \mathrm{Cl}_{2}$; ${ }^{f}$, In $5.0 \mathrm{~mL} \mathrm{THF} ; \mathrm{g}, \mathrm{ROH}=\mathrm{BnOH}$; h, $\mathrm{ROH}={ }^{\mathrm{i}} \mathrm{PrOH}$

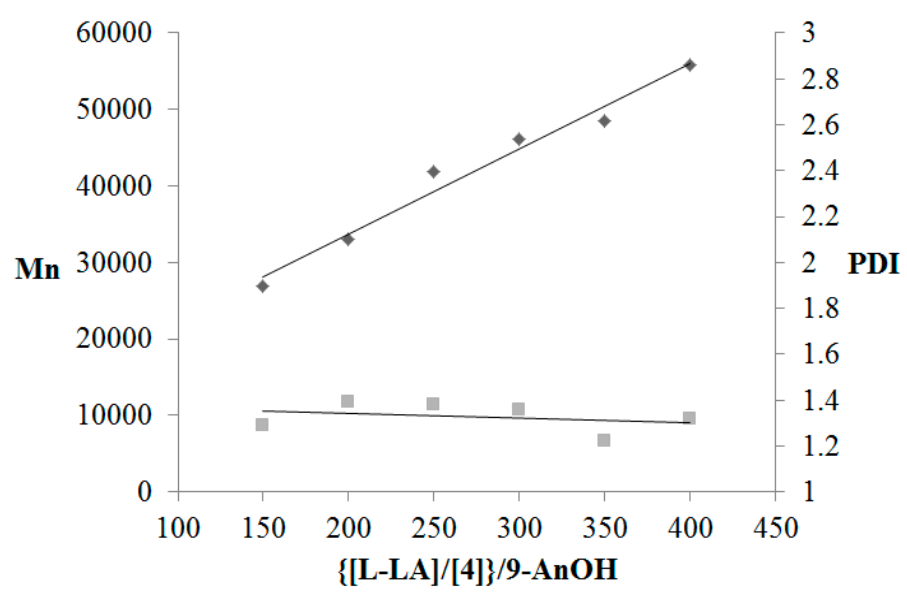

Figure 2. Polymerization of L-LA catalyzed by 4 in toluene at $30^{\circ} \mathrm{C}(\mathrm{PDI}=\mathrm{Mw} / \mathrm{Mn}$ in Table 3$)$. 
The "immortal" character was examined using 2-4 equivalents 9-AnOH as chain transfer agent to produce polymers with reasonable $M$ n values (Table 1, Entries 20-22, compared to entries 17, 15 , and 14 , respectively). The end group analysis is demonstrated by the ${ }^{1} \mathrm{H}$ NMR spectrum of polylactide (PLA-100) catalyzed by 4 in the presence of $9-\mathrm{AnOH}$, which is shown in Figure 3.

Peaks are assignable to the corresponding protons in the proposed structure. The mechanism might be similar to that reported on magnesium complexes bearing pendant indolyl ligand, indicating the active magnesium alkoxide species might form first, followed by the coordination-insertion mechanism [28].
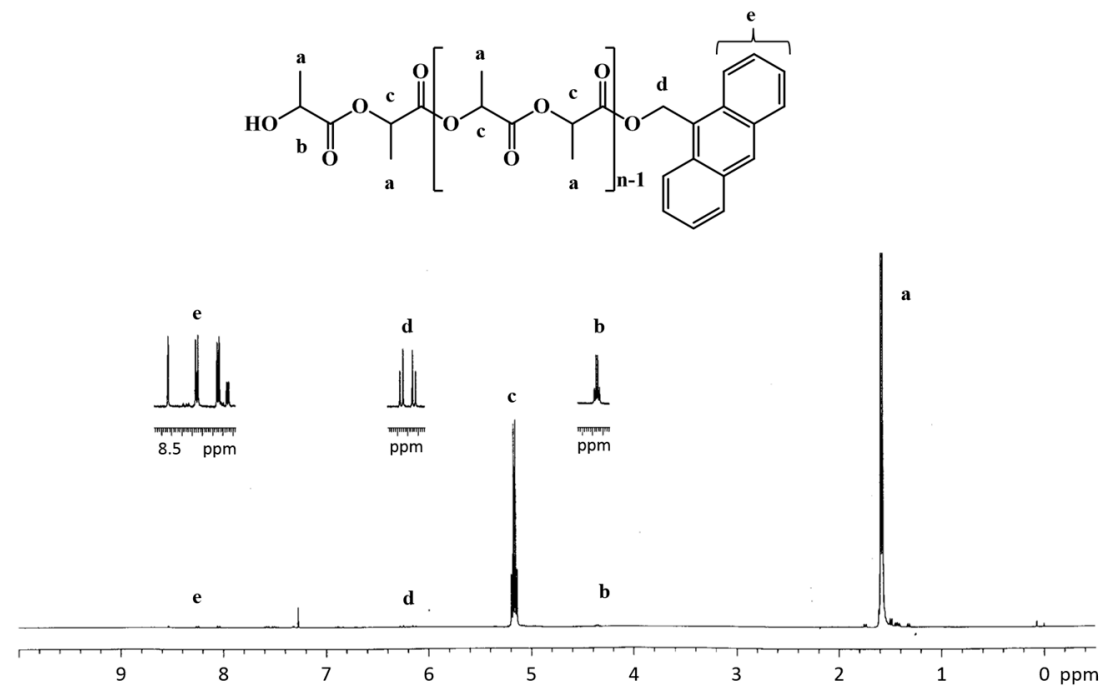

Figure 3. ${ }^{1} \mathrm{H}$ NMR spectrum of PLA-100 initiated by 4 in the presence of $9-\mathrm{AnOH}$ in toluene at $0{ }^{\circ} \mathrm{C}$.

\section{Conclusions}

Four indole ligand precursors containing pendant pyrazolyl functionalities have been prepared. The novel magnesium bis-indolyl complexes 1-4 have been synthesized and fully characterized by NMR spectroscopic studies and elemental analyses. Due to the steric hindrance of ligands, only complex 1 bearing two coordinated THF molecules in cis-configuration has been synthesized and confirmed by single-crystal X-ray crystallography. However, the crowded environment around the metal center of $\mathbf{1}$ might prevent the coordination of monomers or alcohols and result in poor catalytic activities. Under optimized condition, complex 4 demonstrated both living and immortal characters but with poor PDIs values (1.20-1.42). Preliminary studies on fine-tuning modification of indole ligands with different substituents and their application in the synthesis of metal complexes are currently underway.

Acknowledgments: We would like to thank the Ministry of Science and Technology of China for financial support (grant number MOST 104-2113-M-005-014-).

Author Contributions: Chi-Tien Chen conceived and designed the experiments and wrote the paper; Deng-Hao Lin performed the experiments; and Kuo-Fu Peng performed X-ray measurement.

Conflicts of Interest: The authors declare no conflict of interest.

\section{References}

1. Uhrich, K.E.; Cannizzaro, S.M.; Langer, R.S.; Shakesheff, K.M. Polymeric systems for controlled drug release. Chem. Rev. 1999, 99, 3181-3198. [CrossRef] [PubMed]

2. Albertsson, A.-C.; Varma, I.K. Recent developments in ring opening polymerization of lactones for biomedical applications. Biomacromolecules 2003, 4, 1466-1486. [CrossRef] [PubMed] 
3. Dechy-Cabaret, O.; Martin-Vaca, B.; Bourissou, D. Controlled ring-opening polymerization of lactide and glycolide. Chem. Rev. 2004, 104, 6147-6176. [CrossRef] [PubMed]

4. Williams, C.K. Synthesis of functionalized biodegradable polyesters. Chem. Soc. Rev. 2007, 36, 1573-1580. [CrossRef] [PubMed]

5. Tong, R.; Cheng, J. Paclitaxel-initiated, controlled polymerization of lactide for the formulation of polymeric nanoparticulate delivery vehicles. Angew. Chem. Int. Ed. 2008, 47, 4830-4834. [CrossRef] [PubMed]

6. O'Keefe, B.J.; Hillmyer, M.A.; Tolman, W.B. Polymerization of lactide and related cyclic esters by discrete metal complexes. J. Chem. Soc. Dalton Trans. 2001. [CrossRef]

7. Wu, J.; Yu, T.-L.; Chen, C.-T.; Lin, C.-C. Recent developments in main group metal complexes catalyzed/initiated polymerization of lactides and related cyclic esters. Coord. Chem. Rev. 2006, 250, 602-626. [CrossRef]

8. Platel, R.H.; Hodgson, L.M.; Williams, C.K. Biocompatible initiators for lactide polymerization. Polym. Rev. 2008, 48, 11-63. [CrossRef]

9. Labet, M.; Thielemans, W. Synthesis of polycaprolactone: A review. Chem. Soc. Rev. 2009, 38, 3484-3504. [CrossRef] [PubMed]

10. Wheaton, C.A.; Hayes, P.G.; Ireland, B.J. Complexes of $\mathrm{Mg}$, $\mathrm{Ca}$ and $\mathrm{Zn}$ as homogeneous catalysts for lactide polymerization. Dalton Trans. 2009. [CrossRef] [PubMed]

11. Stanford, M.J.; Dove, A.P. Stereocontrolled ring-opening polymerisation of lactide. Chem. Soc. Rev. 2010, 39, 486-494. [CrossRef] [PubMed]

12. Sutar, A.K.; Maharana, T.; Dutta, S.; Chen, C.-T.; Lin, C.-C. Ring-opening polymerization by lithium catalysts: An overview. Chem. Soc. Rev. 2010, 39, 1724-1746. [CrossRef] [PubMed]

13. Arbaoui, A.; Redshaw, C. Metal catalysts for 3-caprolactone polymerization. Polym. Chem. 2010, 1, 801-826. [CrossRef]

14. Ajellal, N.; Carpentier, J.-F.; Guillaume, C.; Guillaume, S.M.; Helou, M.; Poirier, V.; Sarazin, Y.; Trifonov, A. Metal-catalyzed immortal ring-opening polymerization of lactones, lactides and cyclic carbonates. Dalton Trans. 2010, 39, 8363-8376. [CrossRef] [PubMed]

15. Kuo, P.-C.; Chang, J.-C.; Lee, W.-Y.; Lee, H.M.; Huang, J.-H. Synthesis and characterization of lithium and yttrium complexes containing tridentate pyrrolyl ligands. Single-crystal $\mathrm{X}$-ray structures of $\left\{\mathrm{Li}\left[\mathrm{C}_{4} \mathrm{H}_{2} \mathrm{~N}\left(\mathrm{CH}_{2} \mathrm{NMe}_{2}\right)_{2}-2,5\right]\right\}_{2}$ (1) and $\left\{\left[\mathrm{C}_{4} \mathrm{H}_{2} \mathrm{~N}\left(\mathrm{CH}_{2} \mathrm{NMe}_{2}\right)_{2}-2,5\right] \mathrm{YCl}_{2}(\mu-\mathrm{Cl}) \cdot \mathrm{Li}\left(\mathrm{OEt}_{2}\right)_{2}\right\}_{2}$ (2) and ring-opening polymerization of $\varepsilon$-caprolactone. J. Organometal. Chem. 2005, 690, 4168-4174.

16. Hsieh, K.-C.; Lee, W.-Y.; Hsueh, L.-F.; Lee, H.M.; Huang, J.-H. Synthesis and characterization of zirconium and hafnium aryloxide compounds and their reactivity towards lactide and $\varepsilon$-caprolactone polymerization. Eur. J. Inorg. Chem. 2006, 2006, 2306-2312. [CrossRef]

17. Hsieh, I-P.; Huang, C.-H.; Lee, H.M.; Kuo, P.-C.; Huang, J.-H.; Lee, H.-I.; Cheng, J.-T.; Lee, G.-H. Indium complexes incorporating bidentate substituted pyrrole ligand: Synthesis, characterization, and ring-opening polymerization of $\varepsilon$-caprolactone. Inorg. Chim. Acta 2006, 359, 497-504.

18. Yang, Y.; Li, S.; Cui, D.; Chen, X.; Jing, X. Pyrrolide-ligated organoyttrium complexes. Synthesis, characterization, and lactide polymerization behavior. Organometallics 2007, 26, 671-678. [CrossRef]

19. Zi, G.; Wang, Q.; Xiang, L.; Song, H. Lanthanide and group 4 metal complexes with new chiral biaryl-based NNO-donor ligands. Dalton Trans. 2008. [CrossRef] [PubMed]

20. Broomfield, L.M.; Wright, J.A.; Bochmann, M. Synthesis, structures and reactivity of 2-phosphorylmethyl-1H-pyrrolato complexes of titanium, yttrium and zinc. Dalton Trans. 2009. [CrossRef] [PubMed]

21. Ho, S.-M.; Hsiao, C.-S.; Datta, A.; Hung, C.-H.; Chang, L.-C.; Lee, T.-Y.; Huang, J.-H. Monomeric, dimeric, and trimeric calcium compounds containing substituted pyrrolyl and ketiminate ligands: synthesis and structural characterization. Inorg. Chem. 2009, 48, 8004-8011. [CrossRef] [PubMed]

22. Du, H.; Velders, A.H.; Dijkstra, P.J.; Zhong, Z.; Chen, X.; Feijen, J. Polymerization of lactide using achiral bis(pyrrolidene) schiff base aluminum complexes. Macromolecules 2009, 42, 1058-1066. [CrossRef]

23. Katiyar, V.; Nanavati, H. Ring-opening polymerization of L-lactide using $N$-heterocyclic molecules: Mechanistic, kinetics and DFT studies. Polym. Chem. 2010, 1, 1491-1500. [CrossRef]

24. Qiao, S.; Ma, W.-A.; Wang, Z.-X. Synthesis and characterization of aluminum and zinc complexes supported by pyrrole-based ligands and catalysis of the aluminum complexes toward the ring-opening polymerization of $\varepsilon$-caprolactone. J. Organometal. Chem. 2011, 696, 2746-2753. [CrossRef] 
25. Huang, W.-Y.; Chuang, S.-J.; Chunag, N.-T.; Hsiao, C.-S.; Datta, A.; Chen, S.-J.; Hu, C.-H.; Huang, J.-H.; Lee, T.-Y.; Lin, C.-H. Aluminium complexes containing bidentate and symmetrical tridentate pincer type pyrrolyl ligands: Synthesis, reactions and ring opening polymerization. Dalton Trans. 2011, 40, 7423-7433. [CrossRef] [PubMed]

26. Hsueh, L.-F.; Chuang, N.-T.; Lee, C.-Y.; Datta, A.; Huang, J.-H.; Lee, T.-Y. Magnesium complexes containing $\eta 1$ - and $\eta 3$-pyrrolyl or ketiminato ligands: Synthesis, structural Investigation and $\varepsilon$-caprolactone ring-opening polymerisation. Eur. J. Inorg. Chem. 2011, 2011, 5530-5537. [CrossRef]

27. Li, G.; Lamberti, M.; Mazzeo, M.; Pappalardo, D.; Roviello, G.; Pellecchia, C. Anilidopyridyl-pyrrolide and anilidopyridyl-indolide group 3 metal complexes: highly active initiators for the ring-opening polymerization of rac-lactide. Organometallics 2012, 31, 1180-1188. [CrossRef]

28. Peng, K.-F.; Chen, Y.; Chen, C.-T. Synthesis and catalytic application of magnesium complexes bearing pendant indolyl ligands. Dalton Trans. 2015, 44, 9610-9619. [CrossRef] [PubMed]

29. Wang, L.; Cui, D.; Hou, Z.; Li, W.; Li, Y. Highly cis-1,4-selective living polymerization of 1,3-conjugated dienes and copolymerization with $\varepsilon$-caprolactone by bis(phosphino)carbazolide rare-earth-metal complexes. Organometallics 2011, 30, 760-767. [CrossRef]

30. Cacchi, S.; Fabrizi, G. Synthesis and functionalization of indoles through palladium-catalyzed reactions. Chem. Rev. 2005, 105, 2873-2920. [CrossRef] [PubMed]

31. Dalpozzo, R.; Bartoli, G. Bartoli indole synthesis. Curr. Org. Chem. 2005, 9, 163-178. [CrossRef]

32. Humphrey, G.R.; Kuethe, J.T. Practical methodologies for the synthesis of indoles. Chem. Rev. 2006, 106, 2875-2911. [CrossRef] [PubMed]

33. Cacchi, S.; Fabrizi, G.; Goggiamani, A. Copper catalysis in the construction of indole and benzo[b]furan rings. Org. Biomol. Chem. 2011, 9, 641-652. [CrossRef] [PubMed]

34. Inman, M.; Moody, C.J. Indole synthesis—Something old, something new. Chem. Sci. 2013, 4, $29-41$. [CrossRef]

35. Sánchez-Barba, L.F.; Garcés, A.; Fajardo, M.; Alonso-Moreno, C.; Fernández-Baeza, J.; Otero, A.; Antiñolo, A.; Tejeda, J.; Lara-Sánchez, A.; López-Solera, M.I. Well-defined alkyl heteroscorpionate magnesium complexes as excellent initiators for the ROP of cyclic esters. Organometallics 2007, 26, 6403-6411. [CrossRef]

36. Schofield, A.D.; Barros, M.L.; Cushion, M.G.; Schwarz, A.D.; Mountford, P. Sodium, magnesium and zinc complexes of mono(phenolate) heteroscorpionate ligands. Dalton Trans. 2009. [CrossRef] [PubMed]

37. Chisholm, M.H.; Gallucci, J.C.; Yaman, G. Synthesis and coordination chemistry of Tp ${ }^{\mathrm{C}} \mathrm{MI}$ complexes where $\mathrm{M}=\mathrm{Mg}, \mathrm{Ca}, \mathrm{Sr}, \mathrm{Ba}$ and $\mathrm{Zn}$ and $\mathrm{Tp}^{\mathrm{C} *}=\operatorname{tris}$ [3-(2-methoxy-1,1-dimethyl)pyrazolyl]hydroborate. Dalton Trans. 2009. [CrossRef] [PubMed]

38. Chen, C.-T.; Hung, C.-C.; Chang, Y.-J.; Peng, K.-F.; Chen, M.-T. Magnesium and zinc complexes containing pendant pyrazolyl-phenolate ligands as catalysts for ring opening polymerisation of cyclic esters. J. Organometal. Chem. 2013, 738, 1-9. [CrossRef]

39. Dobbs, A. Total synthesis of indoles from tricholoma species via bartoli/heteroaryl radical methodologies. J. Org. Chem. 2001, 66, 638-641. [CrossRef] [PubMed]

40. Mukherjee, A.; Subramanyam, U.; Puranik, V.G.; Mohandas, T.P.; Sarkar, A. Pyrazole-tethered heteroditopic ligands and their transition metal complexes: Synthesis, structure, and reactivity. Eur. J. Inorg. Chem. 2005, 2005, 1254-1263. [CrossRef]

41. Sheldrick, G.M. SHELXTL-97, Program for Refinement of Crystal Structures; University of Göttingen: Göttingen, Germany, 1997.

42. Cacchi, S.; Fabrizi, G. Update 1 of: Synthesis and functionalization of indoles through palladium-catalyzed reactions. Chem. Rev. 2011, 111, 215-283. [CrossRef] [PubMed]

43. Taber, D.F.; Tirunahari, P.K. Indole synthesis: A review and proposed classification. Tetrahedron 2011, 67, 7195-7210. [CrossRef] [PubMed]

44. Antilla, J.C.; Baskin, J.M.; Barder, T.E.; Buchwald, S.L. Copper-diamine-catalyzed N-arylation of pyrroles, pyrazoles, indazoles, imidazoles, and triazoles. J. Org. Chem. 2004, 69, 5578-5587. [CrossRef] [PubMed]

45. Johnson, K.R.D.; Kamenz, B.L.; Hayes, P.G. Bis(pyrazolyl)carbazole as a versatile ligand for supporting lutetium alkyl and hydride complexes. Organometallics 2014, 33, 3005-3011. [CrossRef] 
46. Pedrares, A.S.; Teng, W.; Ruhlandt-Senge, K. Syntheses and structures of magnesium pyridine thiolates-Model compounds for magnesium binding in photosystem I. Chem. Eur. J. 2003, 9, $2019-2024$. [CrossRef] [PubMed]

47. Bott, R.K.J.; Schormann, M.; Hughes, D.L.; Lancaster, S.J.; Bochmann, M. Synthesis and structures of ferrocenyl-substituted salicylaldiminato complexes of magnesium, titanium and zirconium. Polyhedron 2006, 25, 387-396. [CrossRef]

48. Li, C.-Y.; Su, J.-K.; Yu, C.-J.; Tai, Y.-E.; Lin, C.-H.; Ko, B.-T. Synthesis and structural characterization of magnesium complexes bearing benzotriazole phenoxide ligands: Photoluminescent properties and catalytic studies for ring-opening polymerization of L-lactide. Inorg. Chem. Commun. 2012, 20, 60-65. [CrossRef]

(c) (9)

(C) 2015 by the authors; licensee MDPI, Basel, Switzerland. This article is an open access article distributed under the terms and conditions of the Creative Commons by Attribution (CC-BY) license (http:/ / creativecommons.org/licenses/by/4.0/). 